\title{
HOMENAGEM AO PROFESSOR GERALDO ATALIBA
}

\section{I - Geraldo Ataliba, publicista maior}

\section{Carlos Velloso}

Ministro do Supremo Tribunal Federal, presidente do Tribunal Superior Eleitoral e professor titular da Universidade de Brasília

Ao cair da tarde do dia 15 de novembro, quando os brasileiros comemoravam a proclamação da República, morreu Geraldo Ataliba, o moderno doutrinador dos princípios republicanos, autor de República e Constituição, livro que Osíris de Azevedo Lopes Filho, em artigo publicado na Folha de S. Paulo, 17/11, classificou de "marco na formação do Estado Democrático de Direito"

Tal como ocorreu com Tancredo Neves, que pregava a liberdade e morreu no dia 21 de abril, dia consagrado a Tiradentes, a morte de Ataliba lembra a advertência de Shakespeare, posta na boca do príncipe Hamlet, de que há, entre o céu e a terra, mais coisas do que pode perceber nossa vã filosofia.

Com Geraldo Ataliba desaparece um dos maiores publicistas brasileiros, talvez o maior dos últimos tempos, que soube conceituar institutos, até então estudados exclusivamente segundo o direito privado, sob o ponto de vista do direito público, especialmente do direito constitucional, assim nas suas linhas maiores e tendo em vista o critério objetivo. $O$ instituto do direito adquirido, ou da irretroatividade da lei, por exemplo, Ataliba o examinou sob o signo do princípio republicano que, com o princípio do federalismo, exercem no sistema constitucional brasileiro "função capitular(...), determinando inclusive como deve se interpretar os demais" (República e Constituição, RT, 1985).

Conheci Geraldo Ataliba em 1969. Eu era juiz em Minas, juiz novo e novato. Ele lia algumas sentenças minhas, cujas cópias eu lhe remetia, e as comentava, em cartas que me mandava. Eu o julgava um homem velho - pois àquela época Ataliba já era jurista um homem gordo, cabelos grisalhos. Por indicação de Carvalho Pinto, para quem Ataliba era o jurista que mais entendia de contribuição de melhoria no Brasil, nós o convidamos a proferir conferência em um seminário promovido, em Belo Horizonte, pela UNA.

Fui buscá-lo no aeroporto. Desceram todos os passageiros e não desembarcou um homem idoso, gordo, cabelos grisalhos. Sobrou um jovem, que 
depois soube que acabara de completar 30 anos, cabelos negros, bigode fino, pasta na mão. "O senhor é, por acaso, o professor Geraldo Ataliba?", indaguei. A resposta veio firme: "Por acaso, não, por obra do velho professor Ataliba Nogueira" Meia hora depois, parecíamos amigos de infância. Éramos jovens. Vinte e sete anos se passaram. A amizade cresceu e se fortaleceu no respeito mútuo, na admiração que sempre nutri pelo jurista e, sobretudo, pelo homem sumamente ético, pelo homem de bem.

Geraldo Ataliba deu grandeza a tudo que fez. Jurista, escreveu centenas de pareceres e doze livros de doutrina, de leitura obrigatória. Professor, ninguém o excedeu nas cátedras que ocupou mediante memoráveis concursos, na PUC-SP e na USP. Mestre de gerações e gerações, deixa um mundo de discípulos nos tribunais, nas academias e nos institutos. Ele foi o líder da Escola Paulista de Direito Tributário. Notável conferencista, com Celso Antônio, seu amigo desde a escola primária, inovou na tribuna: jamais uma conferência pode ser lida e o conferencista deve se comunicar intensamente com o público.

Sua palavra prendia, encantava, eletrizava. Foi assim no Brasil todo, na maioria dos países americanos, em Portugal e na Espanha. Advogado, foi enorme sua contribuição à Justiça. Ataliba, nos tribunais, lembrava Rui: também ele estuchava, destemidamente, da tribuna, na consciência dos juízes, a formidável responsabilidade destes na tarefa de realizar a segurança jurídica, apenas sujeitos à sua ciência e à sua consciência.

De uma feita, em um julgamento, presenciei Ataliba pedir a palavra para dizer a um juiz que a portaria que este teimava em aplicar simplesmente repetia dispositivo da Constituição. E que era muito mais nobre para um juiz invocar a Constituição, que é um ato da nação, do que invocar uma portaria, ato próprio dos porteiros. Ataliba, aliás, costumava dizer que certos juizes, quando se trata de aplicar portarias e decretos, fazem-no até com certo brilhantismo. Mas se se trata de aplicar a Constituição, esses juízes ficam atemorizados e acabam encontrando modo de não enfrentar o tema constitucional.

Geraldo Ataliba viveu intensamente. Foi grande em tudo que fez, repito. Mas ele tinha tranqüilidade na sua base, na sua família. Por isso, ele muito amava sua mulher, Ana, esposa, amiga, companheira; os seus filhos, Fernando, Eduardo e Mariana; as suas noras, Roseli e Alice; o seu genro Marcos, e o seu último amor, a sua netinha Marina - que os netos constituem o último amor de um homem e de uma mulher. 
Ataliba morreu tal como viveu. Em uma de suas últimas conversas, ele disse que no dia em que saísse do hospital haveria uma festa, uma festa muito alegre ou muito triste. Tudo era uma festa na vida de Ataliba. E de Gabriel Garcia Marquez, lembrou a minha filha Ana Flávia, quando velávamos o corpo do nosso amigo, que "nada parece tanto com uma pessoa quanto a forma de sua morte"

É de tradição o Supremo Tribunal Federal não prestar homenagens. Ao que sei, o único advogado que a Corte Suprema homenageou foi Rui Barbosa. Pois o Supremo Tribunal Federal, no último dia 16, quando do sepultamento de Geraldo Ataliba, prestou a este a maior das homenagens. Nesse dia o Supremo Tribunal não pode julgar questões constitucionais porque quatro de seus juízes, inclusive o presidente, Sepúlveda Pertence, foram se despedir do amigo, do mestre, do companheiro de idéias.

O Supremo Tribunal, no dia 16, não teve quorum constitucional. Justa e merecida homenagem da Corte Suprema, a quem cabe guardar e proteger a Constituição, a quem mais a amou, respeitou e reverenciou. 



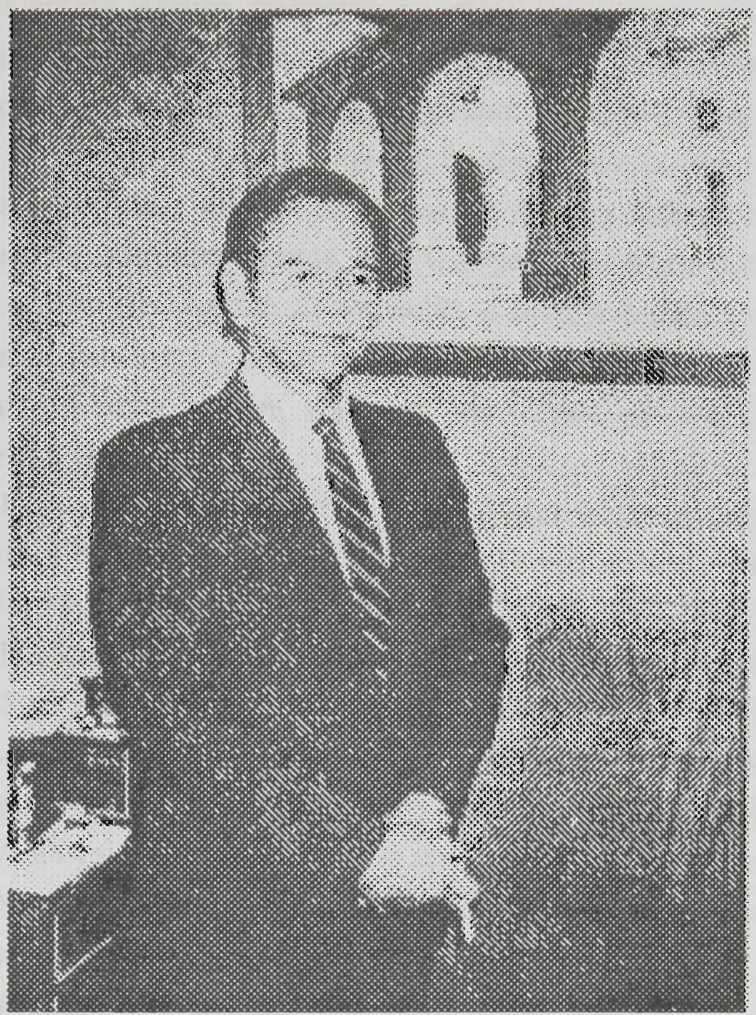

\section{Professor Geraldo Ataliba}

